CZASOPISMO INŻYNIERII LĄDOWEJ, ŚRODOWISKA I ARCHITEKTURY JOURNAL OF CIVIL ENGINEERING, ENVIRONMENT AND ARCHITECTURE

JCEEA, t. XXXIV, z. 64 (2/II/17), kwiecień-czerwiec 2017, s. 199-210, DOI:10.7862/rb.2017.92

\author{
Dawid MROZEK ${ }^{1}$ \\ Magdalena MROZEK ${ }^{2}$ \\ Jan FEDOROWICZ ${ }^{3}$
}

\title{
ANALYSIS OF AN EFFECTIVENESS OF EXPANSION JOINTS IN THE MULTI-FAMILY BUILDING LOADED BY MINING ACTIVITIES
}

\begin{abstract}
There are a lot of possibilities to protect the existing building against the negative impact arising from conducted or projected mining exploitation. These additional loads on the mining area are dependent, among others, from the effects on the surface from an exploitation of coal. One of the basic methods of protection of a building is to carry out the distribution of an object into smaller and regular in a horizontal section parts, what is called dilatation. In consequence of this treatment the decrease of the effort of supporting elements, additional loaded by mining impacts, is expected. The problem is realization of a proper and efficient dilatation in a complicated plan of an existing building.

The paper contains the results of numerical analyzes of a model of a multi-family building with a large and irregular horizontal projection, where two systems of expansion joints were used. The results were compared to the results of the analysis of a model without taking into account additional building protection. The different solutions of the analyzes, where the different directions of mining were included, are presented. The distribution of forces in the bearing walls of the building was analyzed.
\end{abstract}

Keywords: mining influence, ground deformation, building protection, FEM, numerical analyzes

\section{Introduction}

An extremely densely-populated area of Upper Silesia is constantly exposed to impacts resulting from operation related to underground mining of hard coal deposits. As a result of said operation we may observe, inter alia, a constant deformation of land surface. The determination of the rate of such deformation is

${ }^{1}$ Autor do korespondencji / corresponding author: Dawid Mrozek, Politechnika Śląska, Wydział Budownictwa, ul. Akademicka 5, 44-100 Gliwice; tel. 32 2372118; dawid.mrozek@ polsl.pl

2 Magdalena Mrozek, Politechnika Śląska, Wydział Budownictwa, ul. Akademicka 5, 44-100 Gliwice; tel. 32 2372118; dawid.mrozek@polsl.pl

3 Jan Fedorowicz, WST Katowice, ul. Rolna 44, 40-555 Katowice; tel. 3223722 68; jankfedorowicz@gmail.com 
a complex issue, still essential from the point of view of ensuring safety of a building structure. Having known the expected impact of mining areas we are able to assume, as early as at the stage of building structure design, an adequate method and level of protecting the structure. A range of possible solutions will be reduced in the case of an existing building structure which is not resistant to impacts caused by continuous deformation of mining area. One of the methods to reduce the internal forces resulting from additional mining impact on a building is the division of its horizontal projection into regular parts. Such procedure consists in implementing an adequate expansion joint with minimum alterations of the utility functions of the building structure. Execution of expansion joints in an existing building is complex and costly in technical terms and additionally burdened with a significant role of residents' emotions being involved. Having regard to the aforementioned, a profound analysis of the effective selection of expansion joints system is justified. Our studies are conducted on actual multi-family residential building with computer-based numerical method being applied.

\section{Characteristics of the structure and geological-mining conditions}

\subsection{Overview of the structure of the building under the study}

The subject of the analysis is a load-bearing structure of the detached threestaircase residential building built with a use of traditional method and having different heights. From administrative point of view the building structure is

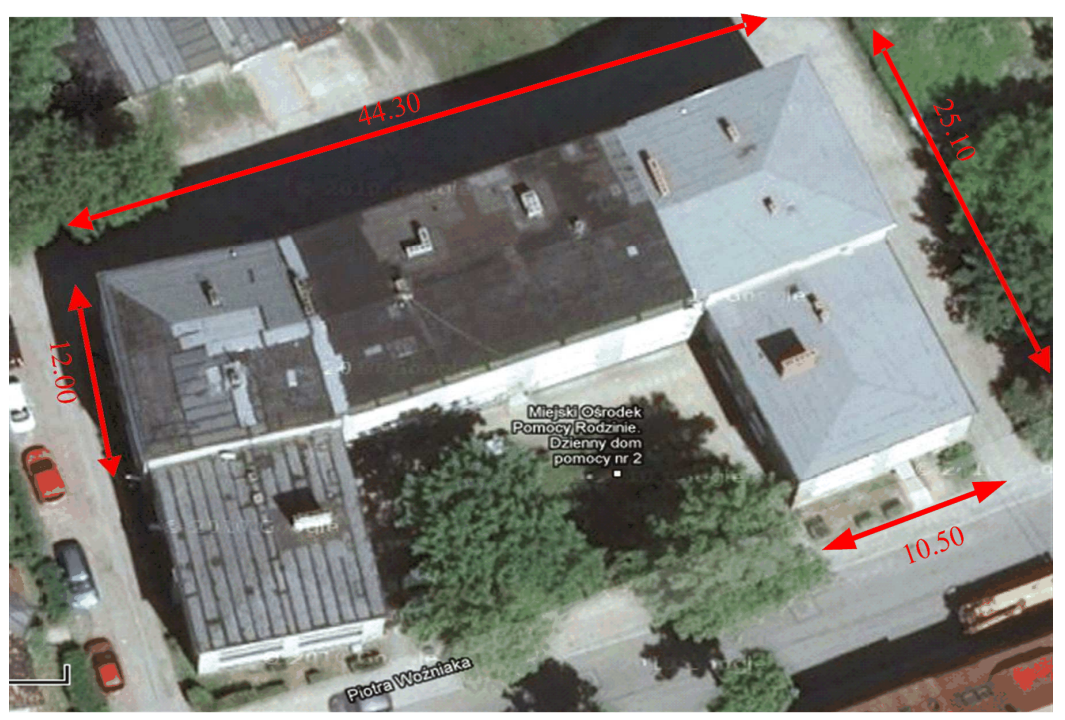

Fig. 1. View of the object

Rys. 1. Widok obiektu 
composed of three buildings the horizontal projection of which is $\mathbf{C}$-shaped. The building structure is founded on one level (all three buildings) with a complete basement (Fig. 1). The particular features of the structure are as follows:

- load bearing system - predominantly longitudinal,

- total length of the building (length of $\mathbf{C}$ letter) $\mathrm{L}=43.30 \mathrm{~m}$,

- total height of the building (measured from the foundation footing) approx. $\mathrm{H}=17.90 \mathrm{~m}$ in central part and $\mathrm{H}=13.80 \mathrm{~m}$ in side parts,

- total broadness of the building $\mathrm{B}=24.40 \mathrm{~m}$ and $10.85 \mathrm{~m}$.

- foundations - made of concrete, on which widened brick masonry walls $60-104 \mathrm{~cm}$ wide and $40 \div 60 \mathrm{~cm}$ high rest,

- load bearing walls of the building made of solid bricks: o external and internal walls of basement and first storey being $51 \mathrm{~cm}$ thick, o external and internal walls of higher storeys made of bricks being $38 \mathrm{~cm}$ thick,

- the ceiling over the basement storey - ceiling DMS,

- wooden ceilings over the higher storeys,

- reinforced concrete lintels, prefabricated,

- reinforced concrete stairs, slab-type, double staircase.

\subsection{Overview of the foundation soil as well as geological-mining conditions in the area of founding of the building under the study}

In the area of the location of the building under the study the geological structure is composed of Quaternary and Triassic layers. The Quaternary layers are composed of boulder clays and sandy deposits whereas Triassic is represented by dolomites and marlstone and limestone deposits. The coal measures are represented by Ruda, saddle and marginal layers. The coal seams are deposited in regular layers with $11^{\circ}$ south-west saddle. Mining in this area was carried out in early 20th century in a number of Ruda series layers and saddle layers deposits. The final mining of hard coal deposits took place in April, 2015.

The building structure under the study has been and still is impacted by the damage of the structure which cause hindrance in regular operation of the building and which deteriorate its current technical condition. Therefore, materials from our archives which are related to the nearest neighbourhood of the building under the study have been used in this document as well as all records concerning the consequences of mining operations carried out in recent years. Below is presented selected information concerning the consequences of mining in the area under the study in which the building concerned is located as well as supplementary information on ore excavations. Table 1 presents characteristics of selected layers. 
Table 1. The main characteristics of exploited decks

Tabela 1. Podstawowe charakterystyki eksploatowanych pokładów

\begin{tabular}{|c|c|c|c|c|c|}
\hline Deck & \begin{tabular}{|c|} 
Distance from the building \\
{$[\mathrm{m}]$}
\end{tabular} & Years & $\begin{array}{c}\text { Deep } \\
{[\mathrm{m}]}\end{array}$ & $\begin{array}{c}\text { Thickens of the deck } \\
{[\mathrm{m}]}\end{array}$ & $\begin{array}{l}\text { Expl. coef. } \\
a\end{array}$ \\
\hline \multicolumn{6}{|c|}{ Done Exploitation } \\
\hline $410 / 1 \mathrm{z} 2$ & 105 & 1932 & 380 & 2,2 & $(0,8)$ \\
\hline $414 / 2$ & 200 & 1955 & 485 & 2,0 & $(0,8)$ \\
\hline $416 / 1 z 2$ & 230 & 1964 & 520 & 2,3 & $(0,8)$ \\
\hline 417 & 0 & 1967 & 535 & 2,0 & $(0,2)$ \\
\hline 418 & 0 & 1970 & 560 & 2,3 & $(0,2)$ \\
\hline 419 & 0 & 1977 & 570 & 2,3 & $(0,2)$ \\
\hline $501 / 1$ & $240-290$ & 1976-1977 & $540-580$ & 2,3 & $(0,2)$ \\
\hline 507 & 0 & 1982 & 720 & 3,2 & $(0,5)$ \\
\hline $414 / 3$ & 245 & 1986 & 520 & 2,0 & $(0,2)$ \\
\hline $507 \mathrm{WD}$ & 0 & 1987 & 720 & 2,3 & $(0,2)$ \\
\hline $504 \mathrm{WD}$ & 0 & 1988-1989 & 660 & 2,4 & $(0,2)$ \\
\hline $507 \mathrm{WG}$ & 130 & 1989 & 710 & 1,8 & $(0,8)$ \\
\hline $414 / 1$ & 0 & 1995 & 475 & 2,8 & $(0,2)$ \\
\hline 419 & 295 & $1999-2000$ & 480 & 2,75 & $(0,2)$ \\
\hline $510 \mathrm{WG}$ & 210 & 2001 & 710 & 1,9 & $(0,7)$ \\
\hline $504 \mathrm{WG}$ & 180 & 2003 & 650 & 3,0 & $(0,8)$ \\
\hline $510 \mathrm{WD}$ & 265 & $2005-2006$ & 695 & 3,0 & $(0,2)$ \\
\hline $510 \mathrm{WD}$ & 100 & 2007 & 705 & 2,8 & $(0,2)$ \\
\hline $510 \mathrm{WD}$ & 140 & 2011 & 710 & 2,4 & $(0,2)$ \\
\hline 620 & 440 & 2014 & 945 & 1,8 & $(0,8)$ \\
\hline \multicolumn{6}{|c|}{ Design Exploitation } \\
\hline $510 \mathrm{WD}$ & 155 & $2013-2017$ & 750 & 2,4 & $(0,2)$ \\
\hline $510 \mathrm{WS}$ & 155 & after 2020 & 745 & 2,8 & $(0,2)$ \\
\hline 615 & 440 & 2016 & 895 & 1,8 & $(0,8)$ \\
\hline $510 \mathrm{WG}$ & 155 & after 2025 & 745 & 2,8 & $(0,2)$ \\
\hline $414 / 2$ & 0 & after 2030 & 565 & 3,0 & $(0,2)$ \\
\hline
\end{tabular}

The geological-mining opinion said that the basic indicators which characterize the deformation of the area surface in relation to post-mining are $\varepsilon_{\max }=2.9 \mathrm{~mm} / \mathrm{m}, T=2,6 \mathrm{~mm} / \mathrm{m}$ and $R_{\min }=-27.0 \mathrm{~km}, w=260 \mathrm{~mm}$. In the case of projected mining until 2030 the most likely total impacts of mining will be characterized by indicators equal to $\varepsilon_{\max }=1.4 \mathrm{~mm} / \mathrm{m}, T=3.3 \mathrm{~mm} / \mathrm{m}, w=933 \mathrm{~mm}$ respectively and fall within group II of mining area category. The opinion also said that the area under consideration was located within the reach of mining tremors caused by operation of the coal mine. Below is listed a record of mining tremors which took place between 2010 and 2013 and the energy of which exceeded $1 \cdot 10^{5} \mathrm{~J}$ plus maximum likely amplitude of acceleration estimated under empirical relationships. The information contained therein lead to the conclusion that in the period under the study several dozen mining tremors the acceleration amplitude of which might have exceeded the value of $150 \mathrm{~mm} / \mathrm{s}^{2}$, took place so it might have exceeded, according to $[1,2,3,4]$ the limit of minor arduousness. The parameters of mining tremors have been listed in Table 2 . 
Table 2. The tabulated summary of selected recorded impacts during the $2010 \div 2013$, w przypadku których oszacowano przyspieszenie o wartości powyżej $150 \mathrm{~mm} / \mathrm{s}^{2}$

Tabela 2. Zestawienie wybranych zarejestrowanych wstrząsów w okresie $2010 \div 2013$ years, where the value of the resultant acceleration was estimated in excess of $150 \mathrm{~mm} / \mathrm{s}^{2}$

\begin{tabular}{|c|c|c|c|c|c|c|c|}
\hline No. & Data & Time & $\mathbf{X}$ & $\mathbf{Y}$ & $\begin{array}{c}\text { Energy } \\
{[\mathrm{J}]}\end{array}$ & $\mathbf{D e c k}$ & $\begin{array}{c}\text { Acceleration } \\
{\left[\mathrm{mm} / \mathrm{s}^{2}\right]}\end{array}$ \\
\hline 1 & $2010-01-07$ & $21: 32: 21$ & 5000 & -3400 & $2,00 \mathrm{E}+07$ & 620 & 158,0 \\
\hline 2 & $2010-01-22$ & $20: 23: 11$ & 5130 & -3170 & $4,00 \mathrm{E}+07$ & 620 & 358,0 \\
\hline 4 & $2010-05-11$ & $13: 42: 37$ & 5370 & -3370 & $9,00 \mathrm{E}+06$ & 620 & 399,7 \\
\hline 5 & $2010-07-30$ & $15: 36: 37$ & 5000 & -3470 & $8,00 \mathrm{E}+06$ & 620 & 300,8 \\
\hline 11 & $2010-09-16$ & $05: 37: 43$ & 4850 & -3470 & $2,00 \mathrm{E}+07$ & 620 & 617,0 \\
\hline 13 & $2010-10-01$ & $16: 49: 17$ & 4900 & -3500 & $9,00 \mathrm{E}+05$ & 620 & 273,0 \\
\hline 15 & $2010-10-09$ & $03: 48: 21$ & 4870 & -3530 & $4,00 \mathrm{E}+06$ & 620 & 711,0 \\
\hline 16 & $2010-10-13$ & $11: 01: 29$ & 4860 & -3520 & $3,00 \mathrm{E}+06$ & 620 & 464,0 \\
\hline 17 & $2010-10-15$ & $12: 39: 54$ & 4930 & -3710 & $5,00 \mathrm{E}+06$ & 620 & 394,0 \\
\hline 23 & $2011-01-11$ & $23: 44: 17$ & 4930 & -3580 & $8,000 \mathrm{E}+07$ & 620 & 174,1 \\
\hline 25 & $2011-06-03$ & $19: 49: 33$ & 5800 & -3460 & $3,000 \mathrm{E}+06$ & 510 & 269,9 \\
\hline 26 & $2011-06-29$ & $17: 56: 53$ & 5790 & -3450 & $3,000 \mathrm{E}+06$ & 510 & 208,2 \\
\hline 28 & $2011-07-19$ & $18: 06: 39$ & 5830 & -3500 & $8,000 \mathrm{E}+06$ & 510 & 311,6 \\
\hline 29 & $2011-09-09$ & $18: 08: 03$ & 5860 & -3520 & $5,000 \mathrm{E}+06$ & 510 & 301,0 \\
\hline 30 & $2011-09-19$ & $17: 47: 08$ & 5840 & -3540 & $4,000 \mathrm{E}+06$ & 510 & 209,1 \\
\hline 31 & $2011-10-08$ & $3: 30: 06$ & 5850 & -3580 & $2,000 \mathrm{E}+06$ & 510 & 220,9 \\
\hline 33 & $2012-09-27$ & $18: 11: 16$ & 5100 & -3220 & $2,000 \mathrm{E}+07$ & 615 & 301,8 \\
\hline 34 & $2012-10-02$ & $12: 43: 20$ & 5290 & -3230 & $9,000 \mathrm{E}+06$ & 615 & 195,2 \\
\hline 36 & $2012-11-21$ & $5: 22: 35$ & 5390 & -3430 & $6,000 \mathrm{E}+07$ & 615 & 310,4 \\
\hline 38 & $2013-01-14$ & $14: 44: 17$ & 5500 & -3340 & $5,000 \mathrm{E}+06$ & 615 & 178,7 \\
\hline
\end{tabular}

\section{The system of expansion joints of the building including numerical equivalents}

The determination of the most efficient division of the building structure with expansion joints being applied was preceded by an analysis of the results acquired in the course of numerical calculations with a use of the finite element method (FEM) $[6,7,8]$. The method provides for the creation of credible models of the building with the following being considered: structural components [5], loads (including mining loads) and expansion joints (as a modification of contact between the walls).

\subsection{Expansion joints adopted}

The implementation of an expansion joint is aimed at reducing internal forces caused by inter alia impacts of mining origin. The areas with mining op- 
eration in progress need specific principles of shaping the joints [1, 2, 3, 4]. The building under the study has a clear "C" letter shape in horizontal projection. Considering the difference in the heights of building wings and its central part a division of the building structure into three parts has been proposed (Fig. 2b). Such operation results in the emergence of one structure with a prolonged projection and two smaller ones. The solution may be modified by dividing the building structure into four parts (Fig. 2d), executed as a result of supplementary (as compared to "B" option) division of the central part into two parts. As in administrative terms the building structure is composed of three buildings one suggested division options includes the layout which reflects such situation (Fig. 2c). The result of "C" option will be the reduction of the central segment length. Seeking the opportunity to compare the work of structures of the expansion joints systems being presented "A" model free of protections (the absence of expansion joints - Fig. 2a) has also been studied. Application of traditional Budzianowski's approach led to the conclusion that the building structure with no expansion joints does not have II category of resistance; hence reinforcement and modernization actions are required.

a)

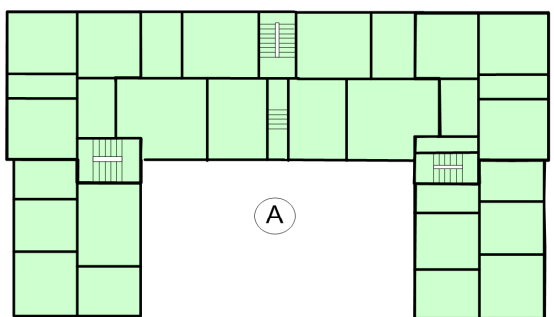

c)

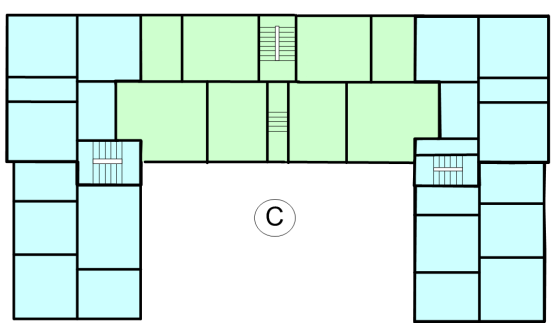

b)

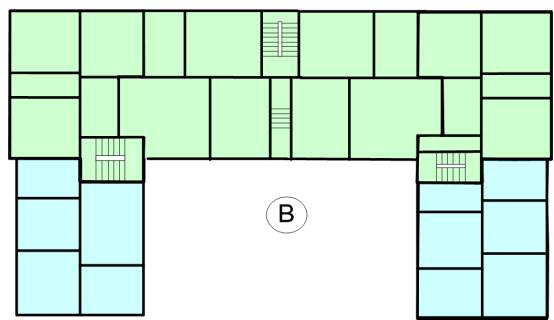

d)

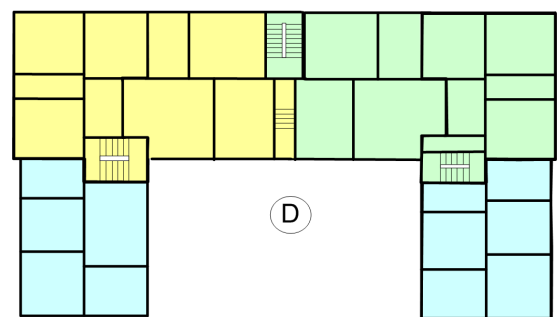

Fig. 2. Expansion joints adopted

Rys. 2. Zastosowany układ dylatacji

The systems of expansion joints as referred herein do not cater for all possibilities of their application in the building under the study. However; every time expansion joints require to be formed at the entire height of the building structure as well as a load bearing wall to be erected to form the completion of the part being expanded by joints. 


\subsection{Description of numerical model being applied}

Numerical models of the building have been made with actual dimensions of the structure being maintained and with a use of FEM $[5,6,7,8]$. The models include window and door openings in the load bearing walls of the building. The models consider direct foundation on the soil described under the vertical modulus of subgrade reaction according to $[1,2]$ as $C_{0}=20 \mathrm{MN} / \mathrm{m}^{3}$. The load bearing walls with various thickness have been described as masonry walls made of bricks with lime-cement mortar. The ceiling above the basement has been modelled as concrete slab with the ceilings made of wood. The work of materials considered in the model is described by linear-elastic relationship. Details concerning material parameters adopted for calculations are contained in Table 3. The building models being applied did not include the structure of wooden roof due to its low stiffness as compared to wall components. The load per roof structure was juxtaposed $\left(q_{\text {roof }}=4.7 \mathrm{kN} / \mathrm{m}^{2}\right)$ and brought to linear load of external walls of the building structure. The calculations considered variable loads applied on ceilings.

Table 3. Tabulated summary of material parameters adopted in the calculation

Tabela 3. Zestawienie parametrów materiałowych przyjmowanych w obliczeniach

\begin{tabular}{|l|c|c|c|c|c|}
\hline Material & $\boldsymbol{\rho}\left[\mathrm{kg} / \mathrm{m}^{3}\right]$ & $\boldsymbol{E}[\mathrm{GPa}]$ & $\boldsymbol{f}_{\boldsymbol{c}}[\mathrm{MPa}]$ & $\boldsymbol{f}_{\boldsymbol{t}}[\mathrm{MPa}]$ & $\boldsymbol{v}$ \\
\hline Masonry & 1900 & 2,1 & 2,1 & 0,4 & 0,20 \\
\hline Concrete & 2400 & 30 & 16 & 1,6 & 0,16 \\
\hline
\end{tabular}

Numerical analyses have been conducted with a use of FEM with a division into finite elements $(F E)$ of the structural part into 4-node square shell elements with a side equal to approx. $10 \mathrm{~cm}$ (Fig. 3b). The division resulted in approx. $170000 \mathrm{FE}$ to which adequate material and geometrical parameters were attributed. The expansion join has been considered by appropriate modelling of segments (Fig. 3a), followed by application of unilateral ties providing for the transfer of compression forces between parts.
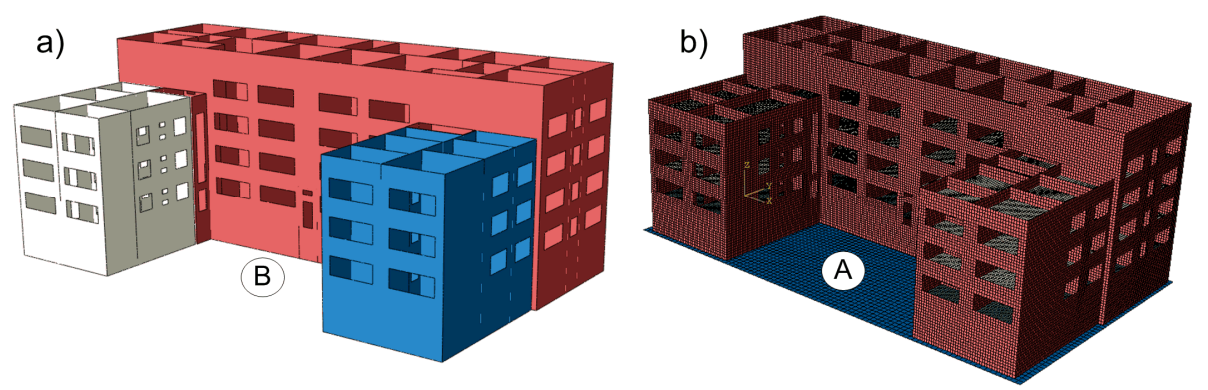

Fig. 3. Numerical model of the object: a) division into parts, b) FEM mesh

Rys. 3. Model numeryczny obiektu: a) podział na części, b) siatka MES 


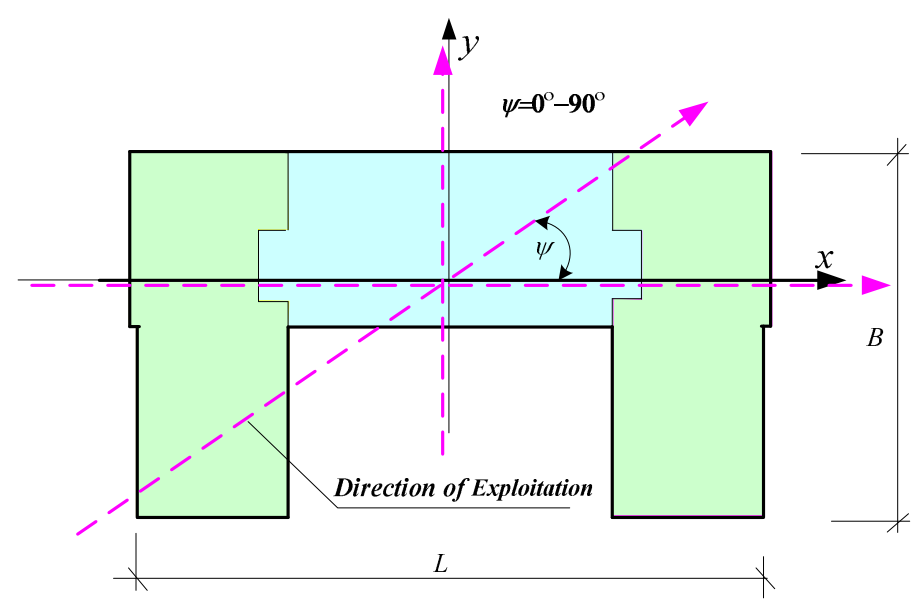

Fig. 4. Analyzed directions of a mining exploitation in view of the object

Rys. 4. Analizowane kierunki prowadzenia eksploatacji górniczej względem obiektu

The impact of mining operation on the building structure has been considered by the impact of a convex subsidence basin of the radius equal to $R=12 \mathrm{~km}$, corresponding to the impact at the level of upper limit of II category of mining area. The studies covered three directions of mining marked in Fig. 4. They were referred to the described axes of the building structure: in accordance with $x$ axis, in accordance with $y$ axis and at $\psi=45^{\circ}$ angle. The process of applying mining load consisted in introduction of defined function of ground displacement which corresponds to the first stage of convex basis formation.

\section{Selected results of the study of expansion joints system}

The effects of implementing expansion joints have been observed by changes in the values of stresses and deformations of wall components. Moreover, the influence of applying expansion joints on the form and values of natural vibrations have been checked.

\subsection{Static response}

The studies resulted in the values of deformation and stresses. The benchmark (base solution) was determined to be the state received in the model free of expansion joints (A) - Fig. 2a, expressing the values acquired in the other models as the percentage share. The selected results of values of vertical stress $\left(\sigma_{22}\right)$, contact stress $\left(\sigma_{12}\right)$, main deformation $\left(\varepsilon_{1}\right)$ and shape deformation $\left(\varepsilon_{12}\right)$ have been contained in Table 4 . The images of deformation distribution of wall elements have been presented in Fig. 5 . 
Table 4. Tabulated summary of impact the expansion on the effort of the load-bearing walls

Tabela 4. Zestawienie wpływu dylatacji na wytężenie ścian nośnych obiektu

\begin{tabular}{|c|c|c|c|c|c|c|c|c|}
\hline \multicolumn{9}{|c|}{ Radius $-R=12 \mathrm{~km}$ on the direction $x-\psi=0^{\circ}$} \\
\hline Model & $\left.\begin{array}{c}\sigma_{22} \\
{[k P a]}\end{array}\right]$ & $\begin{array}{c}\text { Percentage } \\
{[\%]}\end{array}$ & $\begin{array}{c}\sigma_{12} \\
{[k P a]}\end{array}$ & $\begin{array}{c}\text { Percentage } \\
{[\%]}\end{array}$ & $\begin{array}{c}\varepsilon l \\
{[\% o]}\end{array}$ & $\begin{array}{c}\text { Percentage } \\
{[\%]}\end{array}$ & $\begin{array}{c}\varepsilon 12 \\
{[\% o]}\end{array}$ & $\begin{array}{c}\text { Percentage } \\
{[\%]}\end{array}$ \\
\hline $\mathbf{A}$ & 706 & 100 & 486 & 100 & 0,419 & 100 & 0,555 & 100 \\
\hline $\mathbf{B}$ & 666 & 94 & 412 & 85 & 0,390 & 93 & 0,471 & 85 \\
\hline $\mathbf{C}$ & 49 & 7 & 58 & 12 & 0,038 & 9 & 0,067 & 12 \\
\hline $\mathbf{D}$ & 166 & 24 & 128 & 26 & 0,101 & 24 & 0,147 & 26 \\
\hline \multicolumn{9}{|c|}{ Radius $-R=12 \mathrm{~km}$ on the direction $y-\psi=90^{\circ}$} \\
\hline Model & $\begin{array}{c}\sigma_{22} \\
{[k P a]}\end{array}$ & $\begin{array}{c}\text { Percentage } \\
{[\%]}\end{array}$ & $\begin{array}{c}\sigma_{22} \\
{[k P a]}\end{array}$ & $\begin{array}{c}\text { Percentage } \\
{[\%]}\end{array}$ & $\begin{array}{c}\mathcal{E} l \\
{[\%]}\end{array}$ & $\begin{array}{c}\text { Percentage } \\
{[\%]}\end{array}$ & $\begin{array}{c}\varepsilon_{12} \\
{[\% 0]}\end{array}$ & $\begin{array}{c}\text { Percentage } \\
{[\%]}\end{array}$ \\
\hline $\mathbf{A}$ & 326 & 100 & 126 & 100 & 0,160 & 100 & 0,144 & 100 \\
\hline B & 66 & 20 & 43 & 34 & 0,053 & 33 & 0,049 & 34 \\
\hline $\mathbf{C}$ & 290 & 89 & 108 & 85 & 0,102 & 64 & 0,119 & 82 \\
\hline $\mathbf{D}$ & 67 & 21 & 40 & 32 & 0,050 & 31 & 0,046 & 32 \\
\hline \multicolumn{9}{|c|}{ Radius $-R=12 \mathrm{~km}$ on the direction $x y-\psi=45^{\circ}$} \\
\hline Model & $\left|\begin{array}{c}\boldsymbol{\sigma}_{22} \\
{[k P a]}\end{array}\right|$ & $\begin{array}{c}\text { Percentage } \\
{[\%]}\end{array}$ & $\begin{array}{c}\sigma_{12} \\
{[k P a]}\end{array}$ & $\begin{array}{c}\text { Percentage } \\
{[\%]}\end{array}$ & $\begin{array}{c}\varepsilon_{l} \\
{[\%]}\end{array}$ & $\begin{array}{c}\text { Percentage } \\
{[\%]}\end{array}$ & $\begin{array}{c}\varepsilon_{12} \\
{[\% 0]}\end{array}$ & $\begin{array}{c}\text { Percentage } \\
{[\%]}\end{array}$ \\
\hline $\mathbf{A}$ & 1360 & 100 & 546 & 100 & 0,666 & 100 & 0,624 & 100 \\
\hline $\mathbf{B}$ & 439 & 32 & 379 & 69 & 0,313 & 47 & 0,434 & 71 \\
\hline C & 150 & 11 & 50 & 9 & 0,080 & 12 & 0,087 & 14 \\
\hline D & 178 & 13 & 106 & 19 & 0,104 & 16 & 0,121 & 19 \\
\hline
\end{tabular}

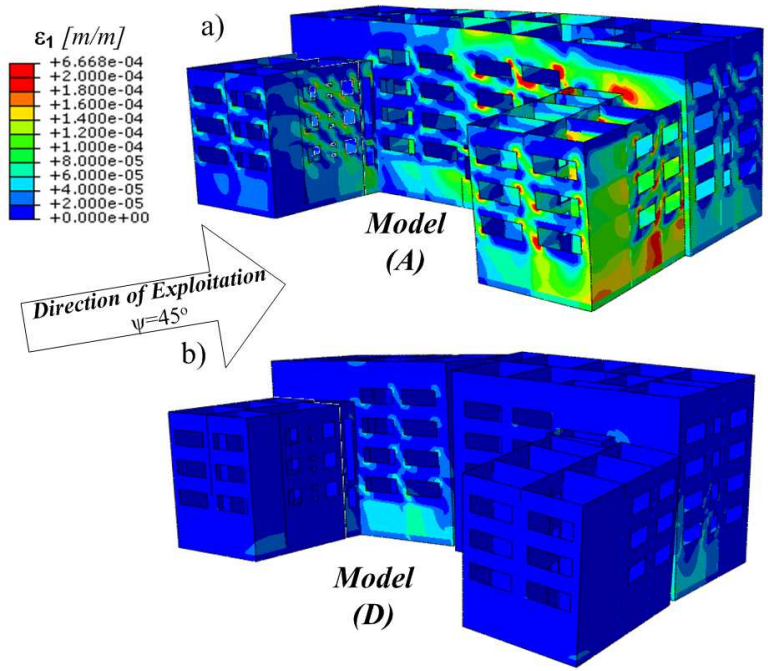

Fig. 5. The distribution of main strain: a) model $\mathbf{A}$, b) model $\mathbf{D}$ Rys. 5. Rozkład odkształceń głównych: a) model A, b) model D 
Considering the largest decrease in structure effort received in the study for efficient selection of expansion joints, the most efficient model is $\mathbf{C}-$ Fig. 2c. There is one prerequisite, namely mining may not be conducted in $\mathrm{Y}$ direction as this model gets the worst results as compared to the other models. The division of the building structure with expansion joints in line with administrative division seemed the most convenient; still not the best one as the results of the dynamic analysis show. Nevertheless, in the worst case i.e. with Y direction mining, the decline of effort reaches the level of about $20 \%$. This means that such expansion joints system might be applied if it were the most convenient from the point of view of consequent use of the building structure. Another possibility for this expansion joints system is to assume a specific direction of mining. In the event the direction is unknown or variable and seeking to obtain better results in effort reduction, the expansion joints system represented by $\mathbf{D}$ model should be applied. This division results in four parts of the building structure - Fig. 2d. It is efficient regardless of the direction of mining operation and the value of effort of wall structure of the building including expansion joints measured with the rates of analyzed stresses and deformations according to D system is by over $70 \%$ lower as compared to $\mathbf{A}$ model, i.e. the model with no expansion joints being applied in the building.

\subsection{Dynamic response}

With reference to the results obtained in static analysis, $\mathbf{A}$ and $\mathbf{D}$ models have been adopted for the second stage, i.e. dynamic analysis. An impact of expansion gap application on the forms and values of natural vibrations frequency has been analyzed. They were compared with the model without expansion joints considering bending shapes on $y$ axis $\left(\omega_{1}\right)$, on $x$ axis $\left(\omega_{2}\right)$ and torsion shape $\left(\omega_{3}\right)$. The values of natural vibrations of models $\mathbf{A}$ and $\mathbf{D}$ are contained in Table 5, and the primary shapes of natural vibrations of models $\mathbf{A}$ and $\mathbf{D}$ are presented in Fig. 6. When comparing the shapes of natural vibrations frequencies of numerical models, the value of natural vibrations frequency in model $\mathbf{D}$ is by $33 \%$ lower as compared to the model without expansion joints. In the event of calculations under response spectrum analysis, by applying a master spectrum of the specific area, lower values of forces are obtained.

Table 5. Tabulated summary of values of the natural frequency of the analyzed models

Tabela 5. Zestawienie wartości częstotliwości drgań własnych analizowanych modeli

\begin{tabular}{|c|c|c|c|c|c|}
\hline Model & $\begin{array}{c}\text { Shape of a natural } \\
\text { frequency }\end{array}$ & $\begin{array}{c}\boldsymbol{\omega} \mathbf{i} \\
{[\mathrm{Hz}]}\end{array}$ & Model & $\begin{array}{c}\text { Shape of a natural } \\
\text { frequency }\end{array}$ & $\begin{array}{c}\boldsymbol{\omega} \\
{[\mathrm{Hz}]}\end{array}$ \\
\hline \multirow{3}{*}{$\boldsymbol{A}$} & bending on the $y$ axis & 3,27 & \multirow{3}{*}{$\boldsymbol{D}$} & bending on the $y$ axis & 2,20 \\
\cline { 2 - 3 } \cline { 5 - 6 } & bending on the $x$ axis & 3,56 & bending on the $x$ axis & 2,69 \\
\cline { 2 - 3 } \cline { 5 - 6 } & torsion & 4,70 & & torsion & 5,16 \\
\hline
\end{tabular}



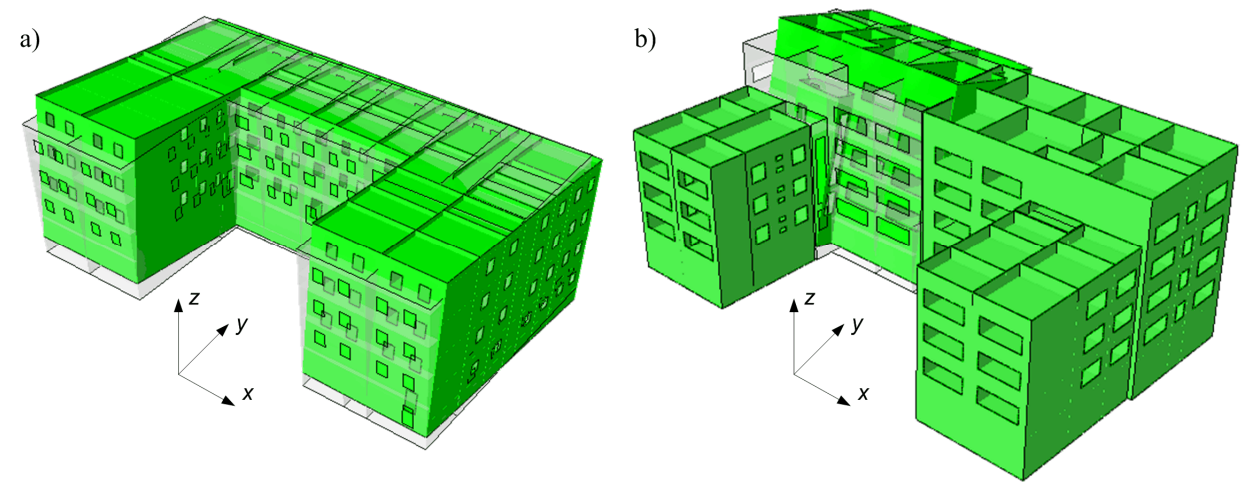

Fig. 6. The comparison of the first shape of the natural frequency: a) model A, b) model D

Rys. 6. Porównanie postaci pierwszych częstotliwości drgań własnych: a) model A, b) model $\mathbf{D}$

\section{Summary}

Economic profitability of protecting the existing building structure against mining impacts with a use of expansion joints depends upon the shape, dimensions of horizontal projection of the building structure and significance of the building structure for its owner. The results of analyses conducted in the study lead to the conclusion that with respect to structure effort:

- under any division of the building body into smaller parts with simpler horizontal projection and equal heights, the effort of structure elements is lower than in the case of non-divided building - even by up to $70 \%$,

- the most efficient system of expansion joints in the case under the study is the division described as model $\mathbf{D}$. In this case the efficiency measured by the decline of the intensity of stress and deformation state in structure elements is noticeable regardless of mining operation in relation to the location of the building structure,

- the application of expansion joints each time resulted in considering the building structure to be resistant to the activity of II category of mining area,

- the system conforming to $\mathbf{D}$ model resulted in the reduction of natural vibrations frequency by $30 \%$.

Conducting the process of protecting a building structure requires different directions of mining operation in relation to the location of the building structure to be considered. In such case the nearest planned mining operation presented in geological-mining opinion may not be solely and exclusively taken into account. 


\section{Bibliography}

[1] Instrukcje, Wytyczne, Poradnik 416/2006. Projektowanie budynków na terenach górniczych. Wydawnictwo ITB, Warszawa 2006.

[2] Instrukcja 364/2007: Wymagania techniczne dla obiektów budowlanych wznoszonych na terenach górniczych, Instytut Techniki Budowlanej, Warszawa 2007.

[3] Praca zbiorowa: Ochrona powierzchni przed szkodami górniczymi. Wyd. Śląsk, Katowice 1980.

[4] Praca zbiorowa: Ochrona obiektów budowlanych na terenach górniczych. Wyd. GIG Katowice 1997.

[5] Fedorowicz J.: Zagadnienie kontaktowe budowla - podłoże gruntowe. Część II. Kryteria tworzenia i oceny modeli obliczeniowych układów konstrukcja budowlana - podłoże górnicze. Zeszyty Naukowe Politechniki Śląskiej, seria Budownictwo, nr 1805, z. 114, Gliwice 2008.

[6] Fedorowicz J., Mrozek M., Mrozek D.: Ochrona budynków murowanych na terenie górniczym. Część 1 - rozważania teoretyczne, Przegląd Górniczy, tom 70, nr 8 (1101), 2014, 85-92.

[7] Fedorowicz J., Mrozek M., Mrozek D.: Ochrona budynków murowanych na terenie górniczym. Część 2 - porównanie analiz klasycznych i współczesnych, Przegląd Górniczy, tom 70, nr 8 (1101), 2014, 93-101.

[8] Fedorowicz J., Mrozek M., Mrozek D.: Ochrona budynków murowych na terenie górniczym. porównanie analiz klasycznych i współczesnych, Modelowanie Inżynierskie, tom 22, nr 53, 2014, 45-51.

\section{ANALIZA EFEKTYWNOŚCI UKŁADÓW DYLATACJI W BUDYNKU WIELORODZINNYM OBCIĄŻONYM WPEYWEM EKSPLOATACJI GÓRNICZEJ}

\section{Streszczenie}

Istnieje szereg możliwości zabezpieczenia istniejącego budynku przed negatywnym wpływem wynikającym z prowadzonej lub prognozowanej eksploatacji górniczej. Te dodatkowe obciążenia na terenie górniczym zależą m.in. od skutków eksploatacji złóż węgla kamiennego na powierzchni. Jedną z podstawowych metod zabezpieczenia obiektu budowlanego jest przeprowadzenie podziału bryły budynku na mniejsze i regularne w rzucie poziomym części, czyli jego dylatowanie. W wyniku takiego działania oczekiwane jest zmniejszenie wytężenia elementów nośnych konstrukcji, obciążonej dodatkowo wpływem górniczym. Problemem jest zrealizowanie prawidłowej i efektywnej przerwy dylatacyjnej w złożonym rzucie istniejącego budynku.

Praca zawiera wyniki analiz numerycznych modelu budynku wielorodzinnego o rozległym i nieregularnym rzucie poziomym, z zastosowaniem trzech układów jego dylatowania. Rezultaty obliczeń porównano z wynikami analizy modelu bez uwzględnienia dodatkowego zabezpieczenia. Dokonano zestawienia rozwiązań z uwzględnieniem różnych kierunków prowadzenia eksploatacji górniczej pod obiektem. Analizie poddano m.in. rozkład sił w ścianach nośnych budynku.

Słowa kluczowe: eksploatacja górnicza, deformacje podłoża, zabezpieczenie budynków, metoda elementów skończonych 